\title{
Comparison of serum soluble edoglin (sEng) level in eary onset preeclampsia, late onset preeclampsia and normal pregnant woman
}

\author{
M. Aldika Akbar, Mita Herdiyantini, Aditiawarman \\ Obstetrics and Gynecology Department, Faculty of Medicine, Airlangga University, Dr. Soetomo Hospital, Surabaya
}

\begin{abstract}
ABSTRAK
Tujuan: Penelitian ini bertujuan untuk mengetahui perbandingan kadar soluble Endoglin serum (sENG) antara preeklampsia tipe dini, preeklampsia tipe lambat dan ibu hamil normal.

Bahan dan Metode: Penelitian ini menggunakan rancangan studi observa-sional analitik secara Cross-Sectional yang dilakukan pada 39 pasien ibu hamil dengan preeklampsia tipe dini, preeklampsia tipe lambat, dan ibu hamil normal, dilakukan di RSUD Dr. Soetomo, RS Universitas Airlangga dan RSUD Dr. M. Soewandhi Surabaya pada bulan Mei - Juli tahun 2016. Konsentrasi serum soluble Endoglin diambil dari darah vena ibu pada saat hamil atau inpartu dan diukur dengan cara metode ELISA.

Hasil: Dari penelitian ini, kami dapatkan kadar serum soluble Endoglin lebih tinggi secara bermakna pada preeklampsia tipe dini dibandingkan dengan preeklampsia tipe lambat dan kehamilan normal $(47,65 \pm 40,17$ vs $13,46 \pm 9,48$ vs $6,11 \pm 1,45$ $\mathrm{ng} / \mathrm{mL} ; \mathrm{p}=0.000)$.

Simpulan: Penelitian ini menunjukkan bahwa gangguan keseimbangan angiogenesis lebih tampak pada PE tipe dini dibandingkan PE tipe lambat. Hal ini mungkin disebabkan disfungsi plasenta, iskemia plasenta, yang memicu produksi faktor antiangiogenesis berlebihan, yang menimbulkan disfungsi endotel menyeluruh lebih didapatkan pada PE tipe dini. (MOG 2017;25:10-15)
\end{abstract}

Kata Kunci: Preeklampsia tipe dini; preeklampsia tipe lambat; kadar soluble Endoglin (s-Eng) serum

\begin{abstract}
Objectives: This study aimed to compare the serum levels of soluble Endoglin (s-Eng) between early onset preeclampsia, late onset preeclampsia and normal pregnant women.

Materials and Methods: This was an analytic observational study (Cross-Sectional) performed on 39 pregnant women with early-onset preeclampsia (EO-PE), late-onset preeclampsia (LO$\mathrm{PE}$ ), and normal pregnancy. The patients were consecutively chosen in Dr. Soetomo Hospital, Airlangga University Hospital and Dr. M. Soewandhi Hospital Surabaya in May-July 2016. The serum concentration of soluble Endoglin were collected by venous puncture taken from maternal circulation and measured by ELISA.

Results: From this study, serum concentrations of soluble Endoglin was higher significantly on the early onset preeclampsia compared with late onset preeclampsia and normal pregnancy $(47,65 \pm 40,17$ vs $13,46 \pm 9,48$ vs $6,11 \pm 1,45 \mathrm{ng} / \mathrm{mL} ; \mathrm{p}=0.000)$. Conclusion: This study shows angiogenic imbalance was more prominent compared in early-onset than late-onset preeclampsia. This may be because the placental dysfunction, placental ischemia, which produce excessive anti angiogenic factors, whic later causing endothelial dysfunction was more related to early onset preeclampsia. (MOG 2017;25: 10-15)
\end{abstract}

Keywords: early onset preeclampsia; late onset preeclampsia; levels of soluble Endoglin (s-Eng) serum,

Correspondence: Muhammad Ilham Aldika Akbar, Department of Obstetrics and Gynecology, Faculty of Medicine, Airlangga University, Dr Soetomo Hospital, Jalan Prof dr Moestopo 6-8, Surabaya 60286, Indonesia, email: muhammad-i-aa@fk.unair.ac.id, dokter_aldi@yahoo.com,dokteraldi@gmail.com

\section{INTRODUCTION}

Preeclampsia is one of the main causes of high maternal morbidity and mortality, especially in developing countries. Several recent studies have shown that the pathogenesis of preeclampsia involves an imbalance between proangiogenic and antiangiogenic factors in the circulation. Endoglins as angiogenic regulators present in chorionic villi at 11 weeks of gestation ${ }^{1}$ Endoglins are commonly found in endothelial cells and placental syncytiotrophoblasts since the first trimester, and have a major role in angiogenic regulation of both the placental and maternal blood vessels in the circulation. ${ }^{2}$ Endoglin receptors bind to TGF- $\beta 1$, causing proliferation and invasion of tropoblasts, vasodilation via eNOS activation (endothelial nitric oxide), and producing vasoprotective element. $^{2,3,4,5}$ TGF- $\beta 1$ has vasoprotective ability through its role in inhibiting: adhesion of neutrophils and $\mathrm{T}$ cells to endothelium, transmigration of neutrophils to the endothelium, and production of pro-inflammatory adhesion molecules in endothelial cells. ${ }^{5,6}$ In pregnancy the crucial role of Endoglin and TGF- $\beta 1$ activity is to regulate the proliferation, differen-tiation and invasion of trophoblasts, and to regulate endothelial cell proliferation, and implantation blastocyst early in pregnancy, as well as other roles in suppressing the maternal immune response in early pregnancy. ${ }^{5}$ It is known that the normal development of pregnancy requires an adequate process of trophoblast invasion. Any interruption in this process can lead to pathological pregnancy, such as preeclampsia.

Soluble Endoglin (sEng) is a form of fractional secretion of Endoglin circulating in the circulation produced by the placenta with a molecular weight of 180 $\mathrm{kD}$. sEng has an antiangiogenic effect, which is by 
interfering the TGF- $\beta 1$ bond at Eng receptors on the cell surface, it will inhibit eNOS activation and result in no vasodilation. It may also cause maternal vascular endothelial dysfunction, and induce endotheliosis as found in preeclampsia. ${ }^{5,7}$ Endoglin's soluble, therefore, is known as an endothelial dysfunction marker.

The pathogenesis of preeclampsia is known to be associated with abnormalities of placental vascular remodeling, which is intitiated with the proliferation and invasion of trophoblast into the spiral artery. This spiral artery remodeling disorder will cause relative vasoconstriction, resulting in decreased blood flow and placental hypoxia leading to placental ischemia. Placental ischemia will further stimulate the releasing of antiangiogenic factors sFlt-1 and sEng. sEng will interfere the bond between TGF- $\beta 1$ and the Eng receptor. ${ }^{2,7}$ Endoglin Soluble is one of the markers involved in endothelial dysfunction, therefore it may also be a preeclampsia marker. Several studies have found elevated levels of sEng in preeclampsia, and increased in 12-16 weeks before the onset of preeclampsia symptoms. ${ }^{2,6,8}$

In preeclampsia, the levels of soluble endoglin released into the maternal circulation increase due to placental ischemia. Decreased levels of TGF- $\beta 1$ and elevated Endoglin soluble levels eventually lead to endothelial damage. ${ }^{7}$ Increased sFlt-1 and sENG are considered to be central factors in endothelial destruction, which is a major feature of preeclampsia.

Currently preeclampsia is classified into early and late onset preeclampsia, which is associated with different pathogenesis, clinical presentation, outcome and prognosis. Early onset preeclampsia may be caused by abnormal placentations characterized by placental lesions and impaired fetal growth, whereas late onset preeclampsia is due to maternal factors and not related to impaired fetal growth. ${ }^{9}$ Because of the differences in placental involvement in both types of preeclampsia, we also suspect that there is also differences in levels of soluble endoglin in maternal serum triggered by the placental ischemia.

The aim of this study was to investigate the soluble serum endoglin levels in pregnant women with early and late-type preeclampsia compared with normal pregnant women at the same gestational age.

\section{MATERIALS AND METHODS}

This was an observational descriptive study with cross sectional methods involving a total of 39 pregnant women with preeclampsia and normal pregnant women, and was conducted in Dr. Soetomo Hospital, Airlangga University Hospital and Dr. M. Soewandhi Hospital Surabaya on May-July 2016. The inclusion criteria for this study were pregnant women with preeclampsia, and normal pregnant women in the gestational age of $\geq 20$ weeks. The exclusion criteria were pregnant women with metabolic and infectious diseases (Chronic Hypertension, Diabetes Mellitus, obesity, asthma, acute respiratory track infection, UTI), and smoking pregnant women.

The concentration of soluble serum endoglin was taken from maternal venous blood and was measured by the ELISA method. sENG level examination was done at PRODIA Laboratory.

\section{RESULTS AND DISCUSSION}

Based on the gestational age, the preeclampsia group was divided into early onset preeclampsia group $(<34$ weeks gestational age), and late onset preeclampsia group ( 234 weeks gestational age). Each groups contained 13 people. The general characteristics of our study subjects are presented in Table 1 below.

Table 1. General Characteristics in Each Groups

\begin{tabular}{|c|c|c|c|c|}
\hline Variable & $\begin{array}{c}\text { Early type } \\
\text { Preeclampsia } \\
\mathrm{N}=13(\%)\end{array}$ & $\begin{array}{c}\text { Late type } \\
\text { Preeclampsia } \\
\mathrm{N}=13(\%)\end{array}$ & $\begin{array}{c}\text { Control } \\
\mathrm{N}=13(\%)\end{array}$ & $\mathrm{p}$ \\
\hline \multicolumn{5}{|l|}{ Age(Year)\# } \\
\hline$<20$ & 0 & 0 & 0 & 0.584 \\
\hline $20-34$ & $9(69.2)$ & $9(69.2)$ & $11(94.6)$ & \\
\hline 235 & 4(39.8) & $4(30.8)$ & $2(15.4)$ & \\
\hline \multicolumn{5}{|l|}{ Parity } \\
\hline Primigravida & $5(38.5)$ & $2(15.4)$ & $4(30.8)$ & 0.458 \\
\hline Multigravida & $6(46.2)$ & $8(61.5)$ & $8(61.5)$ & \\
\hline Grandemulti & $2(15.4)$ & $3(23.1)$ & $1(7.7)$ & \\
\hline BMI & $27.36 \pm 5.96$ & $29.00 \pm 5.49$ & $\begin{array}{c}24.14 \pm \\
5.12\end{array}$ & 0.088 \\
\hline $\begin{array}{l}\text { Gestational } \\
\text { Age (Weeks) }\end{array}$ & $32(24-33)$ & $37(34-39)$ & $33(26-38)$ & $\begin{array}{c}<0.00 \\
01 *\end{array}$ \\
\hline Systolic BP & $160(140-180)$ & $160(140-200)$ & $\begin{array}{c}110(100- \\
124)\end{array}$ & $\begin{array}{c}<0.00 \\
01^{*}\end{array}$ \\
\hline Diastolic BP & $100(90-120)$ & $100(90-140)$ & $70(60-92)$ & $\begin{array}{c}<0.00 \\
01 *\end{array}$ \\
\hline
\end{tabular}

\# Has a normal data distribution based on Kolmogorov-Smirnov and Shapiro-Wilk tests. while other items have abnormal data distribution. $* \mathrm{p}<0.05$

From the description of general characteristics between groups, there was no significant difference in maternal age, parity and Body Mass Index (BMI). Mother age tends to be older in the preeclampsia group (either early or late type) than in the control group.

From the description of risk factors among the study sample groups which include: history of hypertension, history of preeclampsia, parity, maternal age $>35$ years, and obesity, all showed no significant differences as seen in Table 2. 
Table 2. Risk Factor of Each Group

\begin{tabular}{lcccc}
\hline \multicolumn{1}{c}{ Variable } & $\begin{array}{c}\text { Early type } \\
\text { Preeclampsia } \\
\mathrm{N}=13(\%)\end{array}$ & $\begin{array}{c}\text { Late type } \\
\text { Preeclampsia } \\
\mathrm{N}=13(\%)\end{array}$ & $\begin{array}{c}\text { Control } \\
\mathrm{N}=13(\%)\end{array}$ & $\mathrm{p}$ \\
\hline $\begin{array}{l}\text { Hypertension } \\
\text { history }\end{array}$ & 15.4 & 0 & 0 & 0.121 \\
$\begin{array}{l}\text { Parity } \\
\text { Primigravida }\end{array}$ & $5(38.5)$ & $2(15.4)$ & $4(30.8)$ & 0.458 \\
Multigravida & $6(46.2)$ & $8(61.5)$ & $8(61.5)$ & \\
Grandemulti & $2(15.4)$ & $3(23.1)$ & $1(7.7)$ & \\
Age >35years & 30.8 & 30.8 & 15.4 & 0.584 \\
Obesity & 30.8 & 23.1 & 7.7 & 0.333 \\
PE History & 15.4 & 0 & 0 & 0.121 \\
Pregnancy with & 0 & 0 & 0 & - \\
IVF & 0 & 0 & 0 & - \\
DM & 0 & 0 & 0 & - \\
Kidney Disease & 0 & 0 & 0 & - \\
Rheumatic & & & & \\
Disease & 0 & 0 & 0 & - \\
Thrombofilia & 0 & 0 & 0 & - \\
PE Family & & & & \\
History & & & & \\
\hline
\end{tabular}

*significant if $\mathrm{p}<0.05$

From this study, using Kruskal-Walis test, the soluble endoglin levels were respectively: early onset, late onset preeclampsia, and control group (47.65 \pm 40.17 vs. $13.46 \pm 9.48$ vs $6.11 \pm 1,45 \mathrm{ng} / \mathrm{mL} ; \mathrm{p}=0.000)$ as shown in figure 1 below.

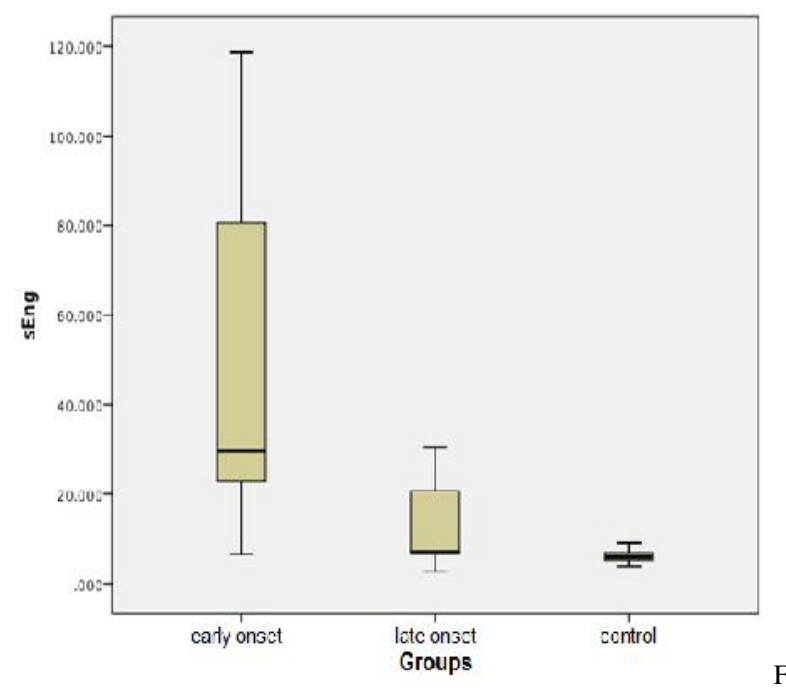

Figure 1. The comparison of soluble Endoglin serum levels in early and late type of preeclampsia cmpared to control group

Further analysis using multivariate test showed significant differences among the three groups. Using MannWhitney's test, we found significant differences between groups: early PE vs control $(p=0.000)$, early-type PE vs late-type PE $(p=0.011)$, and late-type PE with vs ( $p$ $=0.026)$.

\section{Subjects Characteristics}

From both preeclampsia groups we found no characteristic differences that might be major risk factors for preeclampsia, such as age, parity, and body mass index.

Table 3. Multivariate comparation test analysis of soluble Endoglin serum levels in early type preeclampsia, late type preeclampsia, and control

\begin{tabular}{ccrll}
\hline & Control & $\begin{array}{r}\text { Early Type } \\
\text { PE Median } \\
(\text { min-max })\end{array}$ & $\begin{array}{l}\text { Late Type } \\
\text { PE } \\
\text { Median } \\
(\text { min-max })\end{array}$ & $\rho$ \\
\hline s-Eng & $5.84(3.9-$ & $29.64(6.51$ & $\begin{array}{c}7.15(2.72- \\
30.37) b c\end{array}$ & $0.000^{*}$ \\
Levels & $8.99) \mathrm{ac}$ & $-118.75) \mathrm{ab}$ & &
\end{tabular}

* $\rho<0.05$. Shows significant difference among the 3 groups using Kruskal Wallis test.

a : $\rho<0.05$. Shows significant difference between 2 groups, control groups and early type preeclampsia using Mann-Whitney test $\mathrm{b}: \rho<0.05$. Shows significant difference between 2 groups, early type preeclampsia and late type preeclampsia using Mann-Whitney test c : $\rho<0.05$. Shows significant difference between 2 groups, control groups and late type preeclampsia using Mann-Whitney test

The mean age scores of PE groups tend to be older than control group (31.38 vs 32.46 vs 28.62 years, $\mathrm{p}=$ $0.584)$. Maternal age is one of the important risk factors for the occurrence of preeclampsia. Mother's age of more than 40 years is presumed to increase the risk of preeclampsia. ${ }^{10}$ Besides, maternal age more than $35-$ year-old is also associated with an increased risk of pregnancy complications such as diabetes, preeclampsia, placenta previa, miscarriage and pregnancy induced hypertension. The risk of preeclampsia in the second pregnancy also increases with increasing maternal age (1-3x per 5 years of age increasement, $p$ $<0.0001)$. The mechanism behind this risk may be related to placental vascular senescence. ${ }^{11}$ About how maternal age affects on early and late-onset PE events are still unclear today.

We did not find any significant differences among the three groups in terms of parity factor, including the number of primigravids $(38.5 \%$ vs. $15.4 \%$ vs. $30.8 \%)$. In general, preeclampsia is more common in first pregnancy due to genetic or environmental factors. The low risk of multiparous is associated with desensitization following paternal exposure in the placenta during previous pregnancy. ${ }^{10,13}$

We also did not find any significant difference between three groups in terms of body mass index characteristic, although the preeclampsia group tended to have a higher 
BMI than the normal pregnant group $(27.36 \pm 5.96$ vs $29.00 \pm 5.49$ vs $24.14 \pm 5.12 \mathrm{~kg} / \mathrm{m} 2 ; \mathrm{p}=0.088)$.

Obesity is a significant risk factor for the occurrence of preeclampsia. Several studies using large populations showed that obese women have two to three times increased risk for preeclampsia compared to not obese women. A study with a population of 159,072 single pregnancies in USA conducted by Baetan in 2001 showed that obese women (IMT> 30) were significantly at higher risk for preeclampsia (OR: $3.395 \%$ CI 3.0-37), compared to overweight women (OR: $2.095 \% \mathrm{CI}$ 1.8-2.2) and women with normal BMI (OR: $1,395 \%$ CI $1.2-1.5) .{ }^{13}$ Obesity alone increases the risk of preeclampsia presumably because of insulin resistance or hypertrigly-ceride conditions that can trigger endothelial damage, beside of the increasement of inflammation which is caused by the obesity itself.

\section{Soluble Endoglin Serum Levels}

In this study we obtain increasing sEng serum levels, respectively: early-type PE group, late-type PE group and control group, and between each group, we obtained significant differences. sEng has been shown to play an important role in the pathogenesis of preeclampsia. This is because of the nature of the anti-angiogenesis factor that will inhibit the activity of TGF- $\beta 1$ in the placenta, endothelial cells, or maternal circulation. Excessive production of the placenta in preeclampsia disrupts the bonding of TGF- $\beta 1$ to its (Eng) receptor on the cell surface, thus triggering the dysregulation of TGF- $\beta 1$ signals that affects the activation of nitric oxide synthase activation and general vasoconstriction. ${ }^{1}$ Decrease in bioactivity of TGF- $\beta 1$ would interfere maternal vascular endothelial function and induce endotheliosis in renal glomeruli. ${ }^{14}$ Diffuse endothel dysfunction is known to be the predominant feature of preeclampsia. ${ }^{15}$

Several studies have shown that in preeclampsia there is an increase in both placental and maternal sEng serum levels. Research conducted by Rana et al proved that serum sEng levels increase in pregnant women who developed into severe preeclampsia. Since the first trimester of pregnancy, the increasement in s-Eng levels can already be detected, while in the second and third trimesters the levels will increase more. ${ }^{16}$ sEng in the villi has also been found at 11 weeks of gestation and the levels will increase significantly in pregnant women with preeclampsia.1 Several studies have found that, the more severe the preclampsia is, the more sEng is produced by placenta in the serum of the patients, and it decreases right after delivery. sEng administration in the animal model will produce severe preeclampsia characterized by hypertension, proteinuria, glomerular endo- theliosis, and HELLP syndrome. ${ }^{6,8}$ This is to say that sEng is directly related to the pathogenesis of preeclampsia, which can be seen from its association with the severity of the disease.

Increased levels of s-Eng in preeclampsia or in women who will have preeclampsia have been proven by many studies, but the differences between both types of preeclampsia have not been widely discussed. In this study, the levels of sEng in early PE were higher than the late type PE. These results are consistent with Masuyama et al findings, that elevated levels of sEng in early PE are much more visible than late-type PE when compared to their respective controls (early PE vs early control: 88.8 vs 5.7; late PE vs late control: 54.7 vs. $10.8 \mathrm{ng} / \mathrm{ml}$ ), as well as the sFlt-1 and sFlt-1/PlGF ratios.17 Levine et al also found similar results, the increase of sEng in early PE (46.4 vs $9.8 \mathrm{ng} / \mathrm{ml}$ ) was much clearer than the slowtype PE (31.0 vs. $13.3 \mathrm{ng} / \mathrm{ml})$ when compared to the controls respectively. ${ }^{6}$ Wikstrom et al found that serum level in the early-type preeclampsia group was 43 times higher than the controls, while it was only 3 times higher in the late-type preeclampsia group. ${ }^{18}$ Study performed by Maynard in 2010 found that the average of soluble Endoglin (sEng) level increased twice higher in the early-stage PE compared to late-stage PE at 26-32 weeks' gestation, while there is also higher risk of preeclampsia in twin pregnancies compared to single pregnancies. ${ }^{19}$

Study by Levine et al found that the s-Eng levels did not elevate abruptly right when the preeclampsia's emergency conditions were found, but had been increasing since approximately 2-3 months earlier. Along with the increasement of S-Eng content, we also found an increase in the ratio of sFlt1: PlGF. From this study we also found that the levels of sEng elevated earlier in early-type PE or in PE with IUGR, compared to latetype PE or PE without signs of IUGR. ${ }^{6}$ One of the hypotheses regarding the cause of this matter was the "brake angiogenesis" hypothesa that appeared too early/ strong at the beginning of the pregnancy that causes placental vasculogenesis disorders, leading to placental ischemia which is the initial pathogenesis of preeclampsia.

The results of this study support the view that there is a clearer disturbance of uteroplacental insufficiency in early-type PE, while in late-type PE, placental involvement tends to be minimal/absent. This is apparent from the much higher levels of sEng in early-type PE, which production is triggered by the process of placental ischemia, which is one of the major pathogenesis of preeclampsia. Excessive production of soluble Endoglin will disrupt the bioactivity of TGF- $\beta 1$, interfere maternal vascular endothelial function and will induce 
endotheliosis in preeclampsia syndrome. ${ }^{5,20}$ Since the high activity and high levels of sEng may reflect endothelial dysfunction, clinical severity of preeclam-psia should also be associated with sEng level. It is therefore possible that this is one of the causes of poorer maternal-neonatal outcomes in early onset PE compared with late onset $\mathrm{PE}$, due to impaired placental vascular-ization and imbalance angiogenesis factors that happen in early-stage PE. Late-type PE seems to be more related to maternal factors that trigger an increase in maternal inflammatory stress response that exceeds the body tolerance threshold, which will result in a patho-logical response in pregnancy, whose process minimally involve placenta $., 21,22,23,24$

\section{CONCLUSION}

The most dominant HPV genotypes infecting patients with cervical precancerous lesions in this study were HPV 16, HPV 67, HPV 52 and HPV 18, and therefore, HPV types 52 and 67 should be considered to be a second-generation HPV vaccine for protection against cervical cancer incidence in Indonesia.

\section{REFERENCES}

1. Perez L Lopez-Novoa JM. Soluble endoglin: a biomarker or a protagonist in the pathogenesis of preeclampsia. Port J. Nephrol Hypert. 2014;28(3): 185-192

2. Lam C, Lim KH, Karumanchi SA. Circulating angiogenic factors in the pathogenesis and predic-tion of preeclampsia. Hypertension 2005;46: 1077 1085.

3. Jerkic M, Rivas-Elena J, Santibanez J, et al. Endoglin regulates cyclooxygenase-2 expression and activity. Circ. Res. 2006;99;248-56.

4. Ahmed A, Wenda R. Unravelling the theories of pre-eclampsia: are the protective pathways the new paradigm? British Journal of Pharmacology. 2014;172:1574-86.

5. Whitman M, Raftery L. TGF- $\beta$ signaling at The Summit. Development 2005;132:4205-10.

6. Levine RJ, Lam C, Qian C, Yuet al. Soluble endoglin and other circulating antiangiogenic factors in preeclampsia. N Engl J Med. 2006; 355:9921005

7. Omar SZ, Qvist R et al. Angiogenic factors in the pathogenesis and pathophysiology of Preeclampsia: A mini review. Biomedical Research 2010; 21(3); $246-251$.

8. Venkatesha S, Toporsian M, Lam C, et al. Soluble endoglin contributes to the pathogenesis of preeclampsia. Nature Medicine 2006;12(6):642-50.
9. Sibai BM. Biomarker for hypertension-preeclampsia. Are we close yet? AJOG 2007;1-2.

10. Dekker G, Sibai BM. Primary, secondary, and tertiary prevention of preeclampsia. Lancet 2001; 357:209-15

11. Lamminpaa R, Julkunen KV, Gissler M, Heinonen S. Preeklampsia complicated by advnanced maternal age: a registry-based study on primiparous women in Finland 1997-2008. BMC Pregnancy and Childbirth 2012;12(47):

12. Hernandez-Diaz S, Toh S, Cnattingius S. Risk of pre-eclampsia in first and subsequent pregnancies : Prospective cohort study. BMJ 2009;18(338): b2255.

13. Baeten JM, Bukusi EA, Lambe M. Pegnancy complications and outcomes among overweight and obese nulliparaous women. American Journal of Public Health 2001;91(3):

14. Karumanchi SA, Naljayan MV. New developments in the pathogenesis of preeclampsia. Published as : Adv. Chronic Kidney Dis. HHMI Howard Hughes Medical Institute. PubMed Central 2013;20(3): 265-70.

15. Raghupathy R. Cytokines as key players in the pathophysiology of preeclampsia. Medical Principles and Practice 2013;22(Suppl.1):8-19.

16. Rana R, Karumanchi SA, Levine RJ, et al. Sequential changes in antiangiogenic factors in early pregnancy and risk of developing preeclampsia. Hypertension 2007;50:137-42.

17. Masuyama $H$, Nakatsukasa $H$, Takamoto $N$, Hiramatsu Y. Correlation between soluble endoglin, vascular endothelial growth factor receptor-1, and adipocytokines in preeclampsia. The $\mathrm{J}$ of Clin Endocrin \& Metab. 2007; 92(7): 2672-79.

18. Wikstrom AK, Larsson A, Eriksson UJ et al. Placental Growth Factor and Soluble FMS-Like Tyrosine Kinase-1 in Early-Onset Preeclampsia. Am J Obstetricians Gynecologists 2007; 109(6) :138-1374

19. Maynard SE, Moore Simas TA, Bur L et al. Soluble endoglin for the prediction of preeclampsia in a high risk cohort. Hypertension in Pregnancy 2010; 29(3):330-41.

20. Karumanchi SA, Lindheimer MD. Preeclampsia pathogenesis: "Triple A Rating" autoantibodies and antiangiogenic factors. Hypertension 2008;51:9912.

21. Eiland E, Nzerue C, Faulkner M. Preeclampsia 2012. Journal of Pregnancy 2012.

22. Dadelszen PV, Magee LA, Roberts JM. Subclassification of preeclampsia. Hypertens Pregnancy 2003;22:143-148

23. Weiler J, Tong S, Palmer KR, Is fetal growth restriction associated with a more severe maternal phenotype in the setting of early onset pre- 
Akbar et al. : Comparison level of soluble edoglin serum in preeclampsia and normal pregnant woman

eclampsia? A retrospective study. PLoS ONE 2011;6:e26937.

24. Herraiz I, Simon E, Gomez-Arriaga PI, et al. Angiogenesis-related biomarkers (sFlt-1/PlGF) in the prediction and diagnosis of placental dysfunction: An approach for clinical integration. Int J Mol Sci. 2015;16:19009-26; doi: 10.3390/ijms 160819009 